\title{
Fallopian Tube Cancer pT2c TNM Finding v7
}

National Cancer Institute

\section{Source}

National Cancer Institute. Fallopian Tube CancerpT2c TNM Finding V7. NCI Thesaurus. Code C89677.

Fallopian tube cancer with pelvic extension and malignant cells in ascites or peritoneal washings. (from AJCC 7th Ed.) 